Erratum

\title{
Erratum: Filip, S.; et al. Therapeutic Apheresis, Circulating PLD, and Mucocutaneous Toxicity: Our Clinical Experience through Four Years. Pharmaceutics 2020, 12, 940
}

\author{
Stanislav Filip ${ }^{1, *(1)}$, Ondřej Kubeček ${ }^{1}$, Jiři Š paček $^{2}$, Miriam Lánská ${ }^{3}$ and Milan Bláha ${ }^{3}$ \\ 1 Department of Oncology and Radiotherapy, Faculty of Medicine in Hradec Králové, \\ Charles University Prague, 50003 Hradec Králové, Czech Republic; ondrej.kubecek@fnhk.cz \\ 2 Department of Gynecology and Obstetrics, Faculty of Medicine in Hradec Králové, \\ Charles University Prague, 50003 Hradec Králové, Czech Republic; jiri.spacek2@fnhk.cz \\ 3 4th Department of Internal Medicine-Haematology, Faculty Hospital in Hradec Králové, \\ 50005 Hradec Králové, Czech Republic; miriam.lanska@fnhk.cz (M.L.); milan.blaha@fnhk.cz (M.B.) \\ * Correspondence: stanislav.filip@fnhk.cz
}

The following correction has been made to this paper [1]: We would like to inform the readers that our colleague, Jirina Martinkova, asked to be excluded as an author in this communication. Although we regret her decision, we have respectfully fulfilled her request and wish her the best in her future endeavors. All authors accepted this change and signed Change of Authorship Form.

Author Contributions: S.F. and O.K. wrote the article (S.F.-corresponding author), J.Š. consulting of clinical experiences, M.B. and M.L. consulting of plasmafiltration method. All authors have read and agreed to the published version of the manuscript.

Funding: This review was supported by the Ministry of Health CZ, grant number AZV 16-30366A and PROGRES Q40/06.

Conflicts of Interest: The authors declare no conflict of interest.

\section{Reference}

1. Filip, S.; Kubeček, O.; Špaček, J.; Lánská, M.; Bláha, M. Therapeutic apheresis, circulating PLD, and mucocutaneous toxicity: our clinical experience through four years. Pharmaceutics 2020, 12, 940. [CrossRef] [PubMed]

Publisher's Note: MDPI stays neutral with regard to jurisdictional claims in published maps and institutional affiliations.

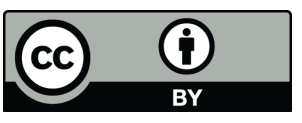

(C) 2020 by the authors. Licensee MDPI, Basel, Switzerland. This article is an open access article distributed under the terms and conditions of the Creative Commons Attribution (CC BY) license (http://creativecommons.org/licenses/by/4.0/). 